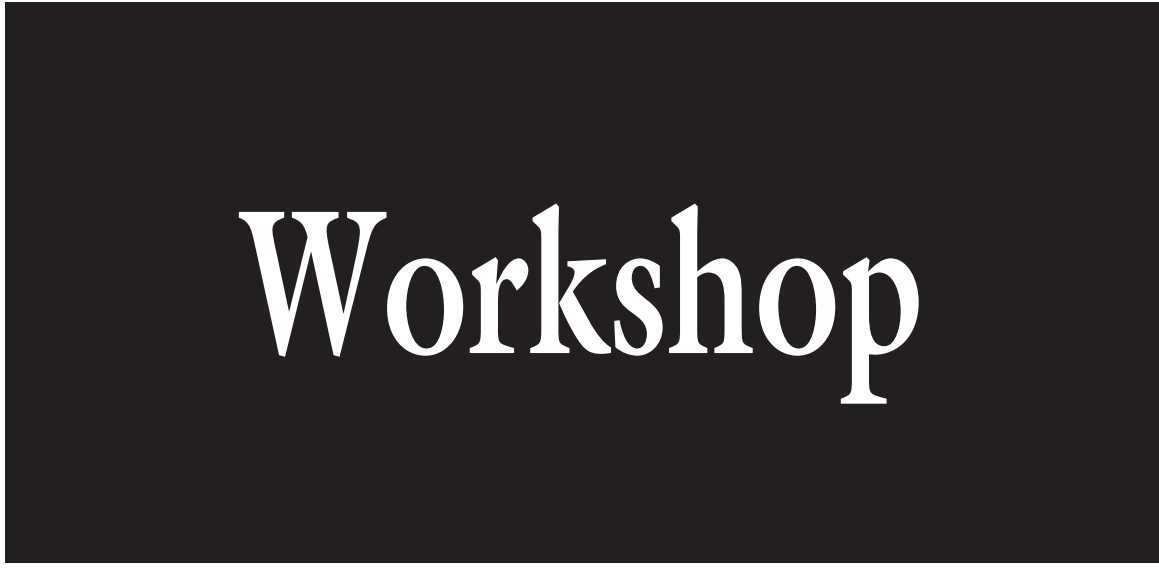

\section{Increasing Effectiveness of Cooperative Extension's Master Gardener Volunteers}

\author{
Ellen M. Bauske ${ }^{1,7}$, Lelia Kelly ${ }^{2}$, Kerry Smith ${ }^{3}$, Lucy Bradley ${ }^{4}$, \\ Timothy Davis ${ }^{5}$, and Pam Bennett ${ }^{6}$
}

ADDITIONAL INDEX WORDs. technology, coordination, management, supervision, web, county, online classroom

SumMARY. Extension Master Gardener (EMG) volunteers are key to effective dissemination of horticultural information to the public. The goal of this workshop was to identify techniques to increase the capacity and effectiveness of EMG volunteers. The workshop focused on projects and tools that reduce the administrative burden of managing volunteers, increase the scope of issues that volunteers are prepared to address, and pool volunteer efforts and resources across county lines. Two online systems for managing and reporting EMG volunteer activities were described. Both systems are intuitive, user-friendly, and updated without the assistance of web managers. Regional web-based, advanced training on specific topics was used to expand educational messages of EMG volunteers and eliminate the costs associated with face-to-face training. Presentations were made using distance learning technologies and resources were shared online. Hosting agents tailored hands-on supporting activities to meet local needs. Volunteers expanded extension outreach by answering noncommercial landscape and garden telephone questions. Many of the administrative, logistical, and resource burdens associated with the EMG helpline phone service were overcome by working across county lines, standardizing training, centralizing supporting resources, and clustering volunteers into regional telephone helpline offices. Other projects and tools presented in the workshop focused on the need to affirm and/or foster the volunteers' connection with the university and the outreach mission of Cooperative Extension.

$\mathrm{T}$ he EMG program began in 1972 in Washington (Grieshop and Rupley, 1984). Horticulture extension agent D. Gibby, overwhelmed by the volume of requests for gardening information, devised a plan to train volunteers in exchange for assistance in educating the public. From that first class of Seattle-area EMG volunteers, the concept has spread to all 50 states and several Canadian provinces. Instructors are generally Cooperative Extension agents or specialists at land-grant universities. the commitments of faculty and staff associated with the program.

Volunteers have demonstrated their value in extension programs across the United States. When George and Laura Bush wanted to preserve the natural landscape of their house near Crawford, TX, Ms. Bush called an EMG volunteer to identify native plants and assist with plant selection (Oberg, 2002). The contribution of EMG volunteers to extension programs is well documented (Martin, 2009). As extension budgets are trimmed and agents struggle to address home horticulture educational issues from evergrowing numbers of urban clientele, the contribution of these volunteers is critical.

Volunteer EMGs are key to effective dissemination of horticultural information to the public. They tend to be relatively long-term residents, slightly older than middle aged, married with children, well educated, and financially secure (Finch, 1997; Rohs and Westerfield, 1996; Schrock et al., 1999). Not only do EMGs work with the public in their capacity as volunteers for Cooperative Extension, but they also apply what they learn in their home landscapes and serve as neighborhood resources for landscape information (O'Callaghan and Robinson, 2005).

The goal of this workshop was to identify techniques to increase the capacity and effectiveness of EMG volunteers and ease the administrative burden on the agents who manage the volunteers. The workshop emphasized free discussion and exchange of ideas. A brief summary of the workshop presentations and discussions is included herein.

\section{Materials and methods}

The workshop was held at the Annual Conference of the American Society for Horticultural Science on 2 Aug. 2010 in Palm Desert, CA, (Kelly, $2010)$ and $\approx 30$ people attended it. It was initiated with three brief presentations highlighting projects and tools that reduce the administrative burden of managing volunteers, increase the scope of issues volunteers are prepared to address, and pool the resources of volunteers spread over several counties. The workshop participants then broke into groups and discussed their own state's innovative and effective programs. A representative of each group 
presented the highlights of their discussion to the full group of workshop participants.

\section{Results and discussion}

WEB-BASED TOOLS FOR MANAGEMENT OF EMG vOLUNTEERS. Recruiting and managing a volunteer group can be a daunting task for agents. Maintaining contact information, volunteer hours, calendars, committee assignments, matching volunteers with tasks, etc., takes considerable time and relies on a set of skills quite different from technical and educational skills that agents may consider their strong suit (Boyd, 2004).

Fortunately, the Internet can create new opportunities for communication, participation, and connectedness (Merrill, 2006). Volunteers are often eager to move online and they expect extension to be technologically advanced, using the Internet for networking and as a clearinghouse of volunteer opportunities (Culp, 2009). Volunteers are also attracted to learning opportunities that upgrade their computer skills (Culp, 2009). Password-protected, interactive, web-based volunteer management tools can enable agents and volunteers to communicate easily and can allow volunteers to assume management responsibilities.

A management tool developed by T. Davis (Clemson University, 2010) is relatively simple and was designed to facilitate the compilation of important data for advocacy and reporting program impact. Volunteers record the number of hours they have volunteered, miles they have traveled, number of contacts they

\footnotetext{
We thank the participants in the ASHS Workshop entitled "Increasing Effectiveness of Master Gardeners: Techniques That Work" on 2 Aug. 2010 for their contribution to this work.

${ }^{1}$ Center for Urban Agriculture, University of Georgia, 1109 Experiment St., Griffin, GA 30223-1797

${ }^{2}$ North Mississippi Research and Extension Center, P.O. Box 1690, Verona, MS 38879

${ }^{3}$ Alabama Cooperative Extension System, 101 Funchess Hall, Auburn University, AL 36849

${ }^{4}$ Department of Horticultural Science, 128 Kilgore Hall, Box 7609, North Carolina State University, Raleigh, NC 27695-7609

${ }^{5}$ Clemson Extension, Sandhills Research and Education Center, 900 Clemson Road, Columbus, SC 29224-3205

${ }^{6}$ Ohio State University Extension, Clark County Office. 4400 Gateway Blvd. Suite 104, Springfield, $\mathrm{OH} 45502$

${ }^{7}$ Corresponding author. E-mail: ebauske@uga.edu.
}

have made, and the type of volunteer service. Preset categories for volunteer service assist with consistent record keeping. Service may be entered as community service, educational service, continuing education, or administrative duties. The home page of this system has leader boards for the counties and individuals reporting the most educational outreach hours. This aspect of the program has served as a strong motivator, availing friendly competition among counties and individuals for "top spots." It also allows coordinators to quickly identify top contributors. The ability to quantify volunteer contributions, and thereby assign economic value to volunteer services, has encouraged participation of both volunteers and the agents who manage them.

The development of a similar web-based tool used in North Carolina was led by L. Bradley (Bradley et al., 2010). The Alaska, Arkansas, and Alabama EMG programs have also purchased this system. The password-protected administrative section has an interactive database directory of volunteers, including contact information, direct links to e-mail, images, profiles, and committee membership (North Carolina State University Cooperative Extension, 2011). It also includes a calendar with links to detailed information about events, including volunteer opportunities and the option to sign up online. As in the Clemson University system, volunteers can log educational and volunteer hours of service. The program management section includes the ability to edit text, add images, add related pages, and upload documents in each program area. It has a frequently asked questions section, an automatically generated subdirectory of committee membership, and a schedule of all upcoming activities for committees. Events created in this section automatically populate the calendar and the volunteer opportunities site.

There are several keys to the success of these online volunteer management systems. They are intuitive, user-friendly, and therefore, easy to learn and operate. The desired information is quickly delivered, and the agents and volunteers can update them without assistance from web managers or secretarial staff.

REgional WEB-BASED ADVANCED TRAINING FOR EMG VOLUNTEERS.
Extension agricultural and natural resource agents are increasingly active in urban water issues. Although agents have played an active role in delivering water messages to the public, time constraints limit direct contact with homeowners who manage and maintain many of the urban landscapes that impact water quality. Volunteers generally receive limited education on urban water issues, though irrigation and drainage are usually included in EMG training programs as they are related to general horticultural issues. Volunteers, agents, and state coordinators identified the need for advanced training to strengthen the knowledge base of EMG volunteers.

Specialists and agents in Alabama, Georgia, and South Carolina developed the 6-h advanced training. All training was conducted using Internet distance education technology such as Adobe Connect (Adobe Systems, San Jose, CA) and Horizon Wimba (Wimba, New York) which allowed a single educator or a small group of educators to make live presentations to volunteers via the Internet. This reduced travel costs, reached many small groups simultaneously, and compounded the impact of the educational efforts. This technology also allowed agents to take advantage of out-of-area specialists and experts without the costs associated with faceto-face meeting.

Local agents hosted the trainings, which were held in libraries, county extension offices, and other meeting rooms. All agents participating in the project had access to resources posted online. The development teams posted supplemental materials and resources for afternoon hands-on training sessions. Participating agents used these resources to develop afternoon activities that complimented their programs, and/or met local needs or interests.

The development team from South Carolina created the first training entitled "Landscape Planning and Design." Intended to assure a baseline of knowledge among volunteers in the three states, the lecture covered seven steps of water smart landscape design. This training also covered water smart retrofits, outlining how to switch a high water use landscape to a low water use landscape. The Georgia team developed the second training, "The Finer Points of Landscape 
Design." This training focused on the identification of landscape pollution sources, pollution transportation and treatment, infiltration and impervious surfaces, irrigation audits, rain gardens, and rain harvesting. The Alabama team developed the third and final day of training entitled "Making the Connection: Our Landscape, Our Stream, Our Watershed." This training taught volunteers to identify healthy streams, focusing on visual, chemical, physi$\mathrm{cal}$, and biological stream assessment. Volunteer opportunities were also discussed.

A total of 293 EMG volunteers were trained at 20 locations with $52,181,51$, and 9 volunteers participating in Alabama, Georgia, South Carolina, and Tennessee, respectively. Pre- and post-training evaluations documented the effectiveness of the training. All groups evaluated were more knowledgeable about the subject matter after training, increasing evaluation scores by $14 \%$ to $22 \%$ (Table 1).

Participants were sent an online follow-up survey 6 months after completing the training and 121 responded (41.3\% response rate). The survey results highlighted the effectiveness of this training method and clearly demonstrated that the training had strengthened the delivery of water quality and quantity messages to homeowners. Most survey respondents (84\%) had shared what they learned in the training with others. Many examples were given, a sample of which are listed below:

- "I have delivered two water efficient presentations and have had several casual conversations focused on the information learned."

- "On tours through the nature center, I point out ways to protect our creeks and stabilize the banks."
- "I helped in the planning of an exhibit at the Sacred Heart Garden Festival featuring a drip system off of an air conditioner unit."

- "We have shared several articles and continue to share tips and information through our bi-monthly newsletter."

- "I have provided information on rain gardens and have installed rain barrels at several elementary schools in the county."

- "Our EMG group began Adopt-A-Stream in January."

The training also affected the recommendations participants made. The majority $(74 \%)$ reported they had changed their recommendations, considerations, or activities as a result of this training. The training impacted participant actions. Over half the volunteers $(53 \%)$ reported they had changed an aspect of their home landscape as a result of their participation in the training. They redesigned planting beds, installed drip irrigation, added more plants to creek banks, used low water use plants, reduced irrigated turf areas, improved and/or installed rain barrels, and created dry creek beds to redirect water. Most volunteers $(91 \%)$ planned to make additional changes in the future as a result of the training.

As a result of this training, EMG volunteers were able to focus their extension educational efforts on water quality and quantity issues that home landscapes impact. A successful regional web-based training has also been implemented in integrated pest management with a similar result. Both trainings allowed the pooling of intellectual resources, eliminated the costs associated with face-to-face training, and affected the educational messages and activities of the volunteers.

Alabama EMG helpline. Volunteers often answer telephones and address gardening questions for homeowners seeking assistance from Cooperative Extension (Grieshop and Rupley, 1984). To successfully answer phones, EMG volunteers must be knowledgeable about the subject matter, have strong organizational, referencing, and telephone skills, and have access to reference materials and current conditions and issues. Over the years, specialists and agents have developed manuals and online resources to help volunteers locate up-to-date responses to questions and situations (Joh and Barkley, 2001; Patterson, 1995). Even with the educational resources available, the training, time, and physical space needed to create an effective telephone team may strain the resources of busy county agents. The strain is compounded when the number of volunteers is limited, reducing the number of calls the team can handle.

In Alabama, the Cooperative Extension System has addressed many logistical issues by pooling resources across county lines. There are 14 extension offices around the state with space allocated for a volunteer office, which collectively support the statewide EMG helpline. The line is dedicated to serving the noncommercial horticulture client. All 14 offices are networked with a "call center" technology via Internet Protocol (IP) telephones. As long as that office's phone is logged-in for the day, the phone will receive calls from the toll-free number.

To accommodate the biological and environmental diversity of the state, call centers are clustered into seven regions, five of which are served by EMG volunteers (and two by agent staff). Callers are asked to choose from a menu that routes their call to the appropriate region. Fliers are circulated to give clients a visual perspective of these regions.

Table 1. Average score on pre- and post-training evaluations administered to Extension Master Gardener volunteers who participated in three 6-h trainings presented in Aug., Sept., and Oct. 2008.

\begin{tabular}{|c|c|c|c|c|c|c|}
\hline & \multicolumn{6}{|c|}{ Training sessions (Avg score in \%) } \\
\hline & \multicolumn{2}{|c|}{$\begin{array}{l}\text { Landscape planning } \\
\text { and design }\end{array}$} & \multicolumn{2}{|c|}{$\begin{array}{c}\text { Finer points of landscape } \\
\text { design }\end{array}$} & \multicolumn{2}{|c|}{$\begin{array}{c}\text { Making the connection: our } \\
\text { landscape, our stream, and our watershed }\end{array}$} \\
\hline & Pre-training & Post-training & Pre-training & Post-training & Pre-training & Post-training \\
\hline Georgia & 71 & 85 & 66 & 86 & 74 & 93 \\
\hline Alabama & 72 & 80 & 66 & 87 & 71 & 92 \\
\hline South Carolina & 70 & 80 & 62 & 82 & 72 & 89 \\
\hline
\end{tabular}

${ }^{2}$ Pre- and post-training evaluations were not administered. 
Volunteer groups active on the helpline receive a 2 to 4 -h training class with their initial EMG certification training series. The training includes office orientation, phone etiquette, familiarization with the operations manual and diagnostic support resources, and assignment of partners (all new volunteers are assigned an experienced helpline mentor their first year). An EMG volunteer is in charge of managing the daily operations in each office. This assignment lasts a full year.

Multiple resources are available to assist EMGs as they volunteer on the phone lines. Collaborative software, which permits document and desktop sharing, is used for regular updates from the state diagnostics laboratory and specialists. Web bookmarks, hard copy files, reference books, and binocular scopes are available in the offices. Regular classes update all volunteers. As an added security for the volunteers, each call is recorded. Agents review a random sample of these calls daily, as well as specific calls upon request of the volunteers.

In 2010, helpline volunteers logged 6315 phone calls and were able to address $87 \%$ of the calls themselves. When they were not confident of their answer or did not know the answer, they were able to assist agents by gathering pertinent information.

It is easier to initiate helpline offices where EMG groups are larger because they have a larger pool of volunteers to assist. However, four of these offices are supported by EMG groups with less than 50 members.

About 500 volunteers work on the helpline statewide. Dedication to the mission of Cooperative Extension has been fostered and supported by the additional training, resources, and experience the helpline EMG volunteers receive. Furthermore, volunteers appreciate the additional education and experience gained from helpline participation and the project supports teamwork, which is very appealing to some volunteers. Volunteers express a strong sense of ownership in the success of this project.

IDEAS PRESENTED IN THE WORKSHOP. Participants in the workshop introduced several innovative ideas. Recognizing the problem of drifting volunteer groups that work independently of Cooperative Extension, many of the suggestions presented affirm and/or foster the volunteer's connection with the university and the outreach mission of Cooperative Extension. These suggestions included the following:

- Remind volunteers of their educational and outreach mission as partners with Cooperative Extension many times during and after their training.

- Bring EMG volunteers to the university campus for seminars and training and introduce them to administrators and researchers, thereby increasing their sense of camaraderie and purpose.

- Connect volunteers through a buddy/mentoring system to help with volunteer retention and affirm the outreach mission.

- Provide EMG volunteers with pre- and or post-training evaluations, charging them with assessment of the impact of their own educational programs.

- Ask volunteers to assist agents by conducting long-term impact assessments by telephone or e-mail, increasing their investment in positive outcomes.

Wolford et al. (2001) reported that EMG volunteers initially rated achievement as the most important motive for beginning service as a volunteer. As they continued to volunteer, affiliation became the most important motive. Intrinsic forms of recognition (e.g., receiving compliments) were also highly rated. Many of the suggestions presented in this workshop acknowledge these powerful motivators. Attention to these motivating factors will increase the effectiveness and impact of EMG volunteers.

Workshop participants also suggested resources and tools to assist in EMG volunteer outreach and to facilitate or increase their capacity as volunteers. Among the suggestions were the following:

- Creation of online EMG speaker's bureau where PowerPoint (Microsoft, Redmond, WA) slide sets and notes are archived.

- PowerPoint development workshops to help EMG volunteers create quality programs and better quality delivery.

- Top 20 questions for each season posted online for EMG volunteers who assist in answering phones, e-mail, or with walk-in clients.

- Searchable databases of homeowner questions (along with the research based answers) to assist volunteers answering questions.

- Additional training in diagnostic fundamentals, empowering EMG volunteers to do onsite work.

- Provide clear guidelines and documentation to enable EMG volunteers to recruit new volunteers and coordinate local training sessions with minimal assistance from agents.

Implementing any of the suggestions presented in this workshop requires a substantial investment of time and resources. Though it may be relatively easy to sacrifice this investment in the short term, the potential long-term rewards for agents, volunteers, and the public are great.

As Cooperative Extension deals with both reduced budgets and increased demand from urban constituents, EMG volunteers will play an increasing role in extension impact and effectiveness, particularly in urban areas. In many states, EMG volunteers may be strong advocates for extension and public service programs. It is, therefore, critical to empower them, affirm their role in extension program delivery, and create resources and tools for managing them with maximum effectiveness.

\section{Literature cited}

Boyd, B.L. 2004. Extension agents as administrators of volunteers: Competencies needed for the future. J. Ext. 42(2). 10 Jan. 2011. <http://www.joe.org/ joe/2004april/a4.php>

Bradley, L.K., C. Cook, and K. Neill. 2010. Web-based tool for managing Master Gardener programs. Acta Hort. 881: 829-831.

Clemson University. 2010. Master Gardener reporting system. 10 Dec. 2010. <http://www.clemson.edu/cemg/State. php>.

Culp, III, K. 2009. Recruiting and engaging baby boomer volunteers. J. Ext. 47(2). 10 Jan. 2011. <http://www. joe.org/joe/2009april/rb2.php>.

Finch, C.R. 1997. Profile of an active Master Gardener chapter. HortTechnology 7:371-376.

Grieshop, J.I. and V. Rupley. 1984. How do you spell relief? Master Gardening! J. Ext. 22(4). 10 Jan. 2011. <http://www. joe.org/joe/1984july/a3.html>.

Joh, L. and D.V. Barkley. 2001. Developing a plant clinic database as an educational 
WORKSHOP

tool for Master Gardener programs. HortTechnology 11:661-665.

Kelly, L.S. 2010. Increasing effectiveness of Master Gardeners: Techniques that work. HortScience 45(8):S20(abstr.).

Martin, J. 2009. USDA Master Gardeners available to help Americans grow safe, healthy food throughout the country. 10 Jan. 2011. <http://www.csrees.usda.gov/ newsroom/news/2009news/07091_ master_gardener.html>.

Merrill, M.V. 2006. Global trends and challenges for volunteering. Intl. J. Volunteer Administration 24:9-14.

North Carolina State University Cooperative Extension. 2011. NCSUgarden.com.
11 Jan. 2011. <http://www.ncsugarden. com/overview.php>.

Oberg, A. 2002. Master Gardeners grow culture of service. USA Today. 10 Jan. 2011. <http://pqasb.pqarchiver.com/ USAToday/search.html?POE=Essentials $>$.

O'Callaghan, A.M. and M.L. Robinson. 2005. Desert bioscape training influences Master Gardeners' practices. J. Ext. 43(2). 10 Jan. 2011. <http://www.joe.org/joe/ 2005april/iw5.shtml>.

Patterson, D. 1995. Master Gardener phone response manual. J. Ext. 33(5). 24 Jan. 2011. <http://www.joe.org/ joe/1995october/tt4.html $>$.
Rohs, F.R. and R.R. Westerfield. 1996. Factors influencing volunteering in the Master Gardener program. HortTechnology 6:281-285.

Schrock, D.S., M. Meyer, P. Ascher, and M. Snyder. 1999. Missouri Master Gardener demographics. J. Ext. 37(5). 24 Jan. 2011. <http://www.joe.org/joe/ 1999 october/rb4.html>.

Wolford, M., K. Cox, and K.I.I.I. Culp. 2001. Effective motivators for Master Gardener volunteer program development. J. Ext. 39(2). 25 Jan. 2011. $<$ http://www.joe.org/joe/200lapril/ rb4.php>. 